\title{
The Paradigm of Global Governance in the Sphere of Peaceful Use of Outer Space
}

\author{
Denis Gugunskiy \\ Department of International Law \\ RUDN University \\ Moscow, Russia \\ Gugunskiy_DA@rudn.university
}

\begin{abstract}
Undoubtedly, formation of the international space law branch became possible thanks to the United Nations, an intergovernmental organization for development of cooperation between states. International intergovernmental organizations such as the United Nations now play an important role in the international legal system. Of course, it is necessary to develop international law as the globalization processes in the world become more intense and accessible due to the rapid progress of technology. Development and application of legally non-binding instruments on exploration of outer space should be based on the existing United Nations treaties, principles and declarations on outer space, they should take full account of the needs and interests of developing countries, should not go beyond the existing capacity of countries to develop space technologies or beyond their level of governance of space activities and should not include introduction of hard-to-meet standards or requirements.
\end{abstract}

Keywords - International space law; Soft law; Space committee; UN; Extraction of resources outside Earth; Long-term sustainability of space activities

\section{INTRODUCTION}

International space law is a set of special norms of the modern common international law governing the relations of states with each other, with international intergovernmental organizations, the relations of such organizations in connection with their space activities, as well as relations establishing an international legal regime for such activities within outer space, the Moon and other celestial bodies [Zhukov, Abashidze, 2014, p. 15]. The centerpiece among the international organizations dealing with international space law is the United Nations, which promotes the use of outer space for peaceful purposes, so that the benefits of this space activity are shared by all countries. Such interest in the peaceful development of outer space appeared shortly after the launch of the first artificial Earth satellite in 1957 by the Soviet Union, and increased as new achievements in the development of space technology were made.

\section{THEORETICAL GROUNDS OF THE RESEARCH}

The first recognition of the fact that international relations could arise in the process of space activities was made in UNGA Resolution 1348 (XIII) of December 13, 1958, which noted "the common interest of mankind in outer space" and the need for discussion within the UN of the nature of "legal problems that may arise in the carrying out of programmes to explore outer space". This resolution also established the Ad Hoc Committee on the Peaceful Uses of Outer Space ${ }^{1}$.

Since that moment, the UN General Assembly has always paid attention to issues related to space activities. Thus, all five international treaties in the field of space law were adopted by the resolutions of the UNGA:

1. Treaty on the Principles of the Activities of States in the Exploration and Use of Outer Space, including the Moon and Other Celestial Bodies, 1967;

2. Agreement on the rescue of cosmonauts, the return of astronauts and the return of objects launched into outer space in 1968;

3. Convention on International Liability for Damage Caused by Space Objects, 1972;

4. Convention on Registration of Objects Launched into Outer Space, 1975;

5. Agreement on the Activities of States on the Moon and Other Celestial Bodies, 1979.

In 1959, Resolution 1472 (XIV) of the UN General Assembly established the main UN body responsible for coordination and implementation of international cooperation in the field of space activities - the UN Committee on the Peaceful Uses of Outer Space (hereinafter - the Committee on Outer Space).

The Committee is engaged in development of programs within the UN, promotes dissemination of information on

${ }^{1}$ Initially, the committee included 18 states: Argentina, Australia, Belgium, Brazil, Canada, Czechoslovakia (now Czech Republic and Slovakia), France, India, Iran, Italy, Japan, Mexico, Poland, Sweden, Union of Soviet Socialist Republics (now Russia), United Arab Republic (currently Egypt), the United Kingdom of Great Britain and Northern Ireland and the United States of America 
space activities, research in this field, and study of legal problems related to exploration of outer space.

87 states are members of this body ${ }^{2}$. The Committee on Outer Space has two subcommittees: one is Scientific and Technical, the other is Legal, which is working on development of legal instruments that accompany rapid technological development in the field of outer space exploration.

The Committee on Outer Space and the two subcommittees located in Vienna hold annual meetings to discuss the issues assigned to them by the UN General Assembly, the reports submitted to them, and the problems raised by member states. Among the most important issues discussed and developed by the Legal Subcommittee in 2018, one can highlight the following ones:

- Capacity-building in space law;

- Use of nuclear power sources in outer space;

- Legal mechanisms relating to space debris mitigation and remediation measures;

- General exchange of information on non-legally binding United Nations instruments on outer space;

- General exchange of views on the legal aspects of space traffic management;

- $\quad$ Long-term sustainability of space activities.

\section{RESEARCH: MAIN PART}

The United Nations Office for Outer Space Affairs plays an important role in the UN activities related to the exploration of outer space, it is a part of the UNGA structure and is engaged in the implementation of its space policy. This Office implements the Program on Space Applications and maintains a register of objects launched into outer space. It also provides support to developing countries in the use of space technology for economic development. In addition, this body is responsible for implementation of decisions of the UNGA and the Committee on Outer Space. The Office also provides technical information and support to member states, international organizations and other UN agencies.

The International Telecommunication Union is the leading international organization in the field of telecommunication, and since 1947 it has been a specialized agency of the United Nations. The ITU has 193 member states. The ITU develops and adopts regulations and other documents regulating, inter

2 Albania, Algeria, Argentina, Armenia, Australia, Austria, Azerbaijan, Bahrain, Belgium, Belarus, Benin, Bolivia, Brazil, Bulgaria, Burkina Faso, Cameroon, Canada, Chad, Chile, China, Colombia, Costa Rica, Cuba, Czech Republic, Denmark, Ecuador, Egypt, El Salvador, France, Germany, Hungary, Ghana, Greece, India, Indonesia, Iran, Iraq, Israel, Italy, Japan, Jordan, Kazakhstan, Kenya, Lebanon, Libya, Luxembourg, Malaysia, Mexico, Mongolia, Morocco, Netherlands, New Zealand, Nicaragua, Niger, Nigeria, Norway, Oman, Pakistan, Peru, Philippines, Poland, Portugal, Qatar, Republic of Korea, Romania, the Russian Federation, Saudi Arabia, Senegal, Sierra Leone, Slovakia, South Africa, Spain, Sri Lanka, Sudan, Sweden, Switzerland, Syrian Arab Republic, Thailand, Tunisia, Turkey, the United Arab Emirates, the United Kingdom of Great Britain and Northern Ireland, the United States of America, Ukraine, Uruguay, Venezuela \& Viet Nam. alia, distribution of radio frequencies for space communications, registers radio frequencies, coordinates the activities of states in this field.

In addition to the mentioned international treaties of the UN General Assembly, the following documents were adopted at different times:

1. Declaration of Legal Principles Governing the Activities of States in the Exploration and Use of Outer Space of 1963;

2. Principles Governing the Use by States of Artificial Earth Satellites for International Direct Television Broadcasting of 1982;

3. Principles Relating to Remote Sensing of the Earth from Space of 1986;

4. Principles Relevant to the Use of Nuclear Power Sources in Outer Space of 1992;

5. Declaration on International Cooperation in the Exploration and Use of Outer Space for the Benefit and in the Interest of All States, Taking into Particular Account the Needs of Developing Countries of 1996, and other documents.

\section{A. Nuclear power sources}

One of the most important achievements of mankind in the modern era was acquisition of nuclear energy and access to outer space. The rapid progress in science and technology conditioned the objective necessity to combine these two areas of human activity, and led to the use of nuclear power sources (NPS) on board of space objects [Piradov, 1985, p. 146]. In January 1978, the Soviet satellite Kosmos-954 crashed in northern Canada [Solntsev, 2011, p. 68-74; Hurwitz, 1989, p. 348-357; Galloway, 1979, p. 131-139]. Luckily, the disaster occurred far from the cities, but serious damage was done to the environment. Kosmos-954 brought up to date the intention to deal with the threat of emergency landings to Earth of objects with NPS on board and became the starting point for preparation by the Committee on Outer Space of the Principles Relevant to the Use of Nuclear Power Sources in Outer Space, which were adopted by the General Assembly without a vote in 1992.

Not being compulsory, this document has a great moral and political weight [Terekhov, 2008, p. 259-260]. However, the work of the Committee did not end there. As a partnership mechanism, the Joint Expert Group of the Scientific and Technical Subcommittee of the Committee and the International Atomic Energy Agency was established, which worked throughout 2007-2009. The Joint Expert Group completed its work one year ahead of schedule, and in 2009 the Safety Framework for Nuclear Power Source Applications in Outer Space was adopted. Thus, the outcome of cooperation between the United Nations and the IAEA turned into a legally non-binding document that guides all launching states.

It should be noted that the UN General Assembly pays special attention to the issues of ensuring security in outer space: it annually adopts resolutions related to prevention of 
an arms race in outer space, and takes measures to ensure transparency and confidence-building in space activities.

The most effective solution regulating the peaceful use of outer space in recent decades is instruments that are not legally binding for states, but states, guided by the goal of sustainable development, follow the provisions of such documents.

Such documents, including the UNGA resolutions, as mentioned earlier, are not legally binding and are interpreted by some contemporary scholars as "soft law". Those scientists, who do not accept the concept of "soft law", provide the following argument: "you can not be a little pregnant; you are either pregnant or not", this means that the law in any case is binding, i.e. it is "hard", and if it is "soft", then it can be anything, but not law. The expression "soft law" is an oxymoron - it is a stylistic figure or stylistic error - a combination of words with the opposite meaning, like, for example, "hot snow" or "dead souls". However, today this oxymoron is a reality that works quite effectively to regulate international relations in the field of peaceful exploration of outer space. If the contract, which is essentially a legally binding document on the basis of a formal analysis, uses the word "should" or "can" instead of "shall", as a result it will still remain a legal obligation, but in fact it will contain more instruction than legal obligation - this leads to a confusion "oblige" anyone to do something, or "allow" [Marboe, 2012, p. 48-49].

\section{B. International Charter "Space and Major Disasters"}

The use of a remote sensing database for activities on mitigation and management of the consequences of natural disasters can serve as an example of efficiency of the "soft law". Since 2000, many leading space agencies have joined the International Charter on Space and Major Disasters, which, in fact, has developed free organizational arrangements for states that are threatened or have been victims of natural or man-made disasters in order to gain quick access to free satellite data that can help them to prevent or mitigate the consequences of such disasters. Although the Charter does not provide for any legal obligations, it is clear that some issues, such as intellectual property rights with respect to data and national security issues, will repeatedly arise and, ultimately, require legal solutions.

At the same time, the Charter proved to be extremely successful (more than 400 references to date from around the world), considerable interest, possibly developing within the international community to gradually transform such a "soft law" regime into a more clear and legally binding regime - as soon as suppliers, in particular, will accumulate enough experience on the actual terms of the Charter to feel confident about the obligations that they will be ready to accept.

In June 2016, Luxembourg announced the creation of a fund of 200 million euros ${ }^{3}$ to attract companies for extraction of mineral resources on asteroids. The Minister of Economy of Luxembourg said that the budget of the fund could be expanded if necessary. Luxembourg has a rich experience in

\footnotetext{
${ }^{3}$ See.: http://fortune.com/2016/06/05/luxembourg-asteroid-mining/
}

launching satellites into orbit. It is worth noting that Luxembourg has launched 26 spacecraft, 24 of which are now in orbit. For comparison: the area of Luxembourg is the same as the area of Moscow.

In 2016 Luxembourg announced that it will develop a legal framework for commercial exploitation of space resources the first set of laws in Europe [Belikova, 2017, P. 404-410]. In 2017 the government of Luxembourg has passed a bill giving companies the rights to space resources they extract from asteroids or other celestial bodies ${ }^{4}$. The United States developed and adopted such document in 2015, it allows "US citizens to participate in commercial exploration and development" of space resources. Along with the United States and Luxembourg, the UAE is developing a national law on space activities, which perhaps will cover issues of resource extraction in space.

Article 1 of the Outer Space Treaty states: "Outer space, including the moon and other celestial bodies, shall be free for exploration and use by all States without discrimination of any kind, on a basis of equality and in accordance with international law, and there shall be free access to all areas of celestial bodies". Thus, no international treaty explicitly prohibits commercial use and extraction of space resources.

A 30-meter asteroid can contain platinum at a cost up to $\$ 50$ billion. However, low gravity can seriously increase the cost of resources extraction. There is also a more ambitious role of the off-Earth mining on asteroids: space bodies may contain gas and water in the form of ice, which can make it possible to create fuel, while turning the asteroids into "fuel stations".

\section{The long-term sustainability of space activities}

The long-term sustainability of space activities is a matter of common concern of the space-faring countries, states benefiting from the use of space technology and commercial satellite operators 5 .

Since 2010, the Committee has included in its agenda an item entitled "Long-term sustainability of space activities" 6 in order to develop guidelines for the long-term sustainability of space activities that should ${ }^{7}$ establish a framework for the possible development and improvement of national and international practices aimed at enhancing the long-term sustainability of space activities, including, inter alia, improvement of safety of space operations and protection of the space environment, taking into account acceptable and reasonable financial and other considerations and the needs and interests of developing countries.

In 2016, 12 principles were approved after reaching a consensus between the states. The Committee noted that, despite the substantial progress made by the Working Group in consideration of many guidelines, more time was needed to consider the remaining draft guidelines and the subsequent preparation of a complete corpus. Having taken into account

\footnotetext{
${ }^{4}$ Art. 1 of the Luxembourg law on the exploration and use of space resources "Space resources are capable of being appropriated".

${ }^{5}$ See.: Un Doc. A/AC.105/C.1/L.303, para. 1

${ }^{6}$ UN Doc. A/64/20), para. 161

${ }^{7}$ UN Doc. A/AC.105/C.1/L.339, para. 9
} 
the foregoing, the Committee agreed to extend the mandate of the Working Group for two more years and, in 2018, two sets of guidelines are expected to be harmonized with a view to preparing a corpus of guidelines with a preamble.

Number equations consecutively. Equation numbers, within parentheses, are to position flush right, as in (1), using a right tab stop. To The long-term sustainability of space activities is a matter of common concern of the space-faring countries, states benefiting from the use of space technology and commercial satellite operators ${ }^{8}$.

Since 2010, the Committee has included in its agenda an item entitled "Long-term sustainability of space activities" in order to develop guidelines for the long-term sustainability of space activities that should ${ }^{10}$ establish a framework for the possible development and improvement of national and international practices aimed at enhancing the long-term sustainability of space activities, including, inter alia, improvement of safety of space operations and protection of the space environment, taking into account acceptable and reasonable financial and other considerations and the needs and interests of developing countries.

In 2016, 12 principles were approved after reaching a consensus between the states. The Committee noted that, despite the substantial progress made by the Working Group in consideration of many guidelines, more time was needed to consider the remaining draft guidelines and the subsequent preparation of a complete corpus. Having taken into account the foregoing, the Committee agreed to extend the mandate of the Working Group for two more years and, in 2018, two sets of guidelines are expected to be harmonized with a view to preparing a corpus of guidelines with a preamble.

\section{CONCLUSION}

Today, space activities are associated with increased risk and potential danger to human life and health, infrastructure, the Earth's environment, the outer space as a whole, and require comprehensive international regulation to ensure the stability, transparency and efficiency of all operations in outer space. In the near future, the nature, process, complexity of space operations and services will increase along with a significant increase in the number of interested parties. In other words, importance of outer space for humanitarian, economic, political, military and strategic purposes will continue to grow for states, communities and private enterprises.

At the moment, only 70 states and organizations have launched spacecraft. 4,291 spacecraft are now in orbit, with a total of 7,498 units that have ever been launched.

The following number of spacecraft has been launched into space in recent years:

$$
\begin{aligned}
& 2018-161^{11} \\
& 2017-453
\end{aligned}
$$

\footnotetext{
${ }^{8}$ See.: Un Doc. A/AC.105/C.1/L.303, para. 1

${ }^{9}$ UN Doc. A/64/20), para. 161

${ }^{10}$ UN Doc. A/AC.105/C.1/L.339, para. 9

${ }^{11}$ July 2018
}

$2016-222$

$2015-223$

$2014-240$

2013 - 209

$2012-134$

$2011-129$

$2010-120$

The number of spacecraft in orbits and in flight as per states and organizations:

Brazil - 25

Canada - 49

China - 348

ESA - 67

France - 127

Germany - 53

India - 89

INTELSAT - 33

Italy - 28

Japan - 178

Korea - 2

Luxembourg - 27

Russia/USSR - 1510

UAE - 9

UK - 82

USA - 1793

It is also worth noting that the first international treaty on space law was signed in 1967, and the last international treaty - in 1979. Thus, for almost 40 years the international community has not adopted new international treaties in the field of space law. This stagnation is caused by the fact that preparation, adoption and ratification of such treaties can drag on not for one year, but perhaps even a decade.

Although the scientific community has certain positions on development of the Convention on Space Law and establishment of the World / International Space Organization, today's global governance is mostly carried out within the UN framework and, in our opinion, it is not possible to adopt any international treaties in the near future, which could regulate this or that area of international space law.

International space law should ensure harmonization of national regimes governing private space operations, and the balance of public and commercial interests in the exploration and use of outer space.

The problem of extracting resources in space as a challenge to the long-term sustainability of space activities 
should be a priority not only for individual states, but also for the international space community as a whole. Thus, there is a need to further refine the guidelines to ensure the long-term sustainability of space activities.

\section{ACKNOWLEDGMENT}

The paper is prepared under the project N 16-18-10315 funded by Russian Science Foundation at Saint Petersburg State University.

\section{REFERENCES}

[1] Galloway E. (1979). United Nations Consideration of nuclear power for satellites. Proceedings 22nd Colloquium, 131-139.

[2] Hurwitz B.A. (1989). Reflection on the Cosmos 954 incident. Proceedings 32nd Colloquium, 348-357.

[3] Marboe I. (Ed.). (2012). Soft Law in Outer Space: The Function of Non-Binding Norms in International Space Law. Wien: Böhlau.

[4] International space law / editor-in-chief A.S. Piradov. - M.: International relations, 1985. - P. 146.

[5] International space law: Textbook / edited by G.P. Zhukova, A.K. Abashidze. - M.: PFUR, 2014.

[6] A.M. Solntsev. Practical guide on the international environmental law: textbook. - M.: RUDN University, 2011 - P. 68-74.

[7] A.D. Terekhov. Resolutions of the UN General Assembly and the space law // Cpntemporary problems of the international space law: Collection of articles / edited by G.P. Zhukova, A.Y. Kapustina. - M.: PFUR, 2008. - P. 259-260.

[8] Belikova K., Badaeva N., FrolovaE., Dudin M. Concept and different types of restrictive business practices in the legal orders of BRICS countries (the case of China, India, Russia and South Africa) // Journal of Advanced Research in Law and Economics. Volume 8, Issue 2, 2017. P. 404-410. 